\title{
NAS FRONTEIRAS DO "HUMANO": OS DEBATES BRITÂNICO E BRASILEIRO SOBRE A PESQUISA COM EMBRIÕES
}

Letícia da Nóbrega Cesarino

Em 1990, o Parlamento britânico aprovou legislação inédita regulando os procedimentos de reprodução assistida e a pesquisa embriológica, legislação esta ainda hoje considerada uma das mais permissivas em vigor no mundo: a Human Fertilisation and Embriology Act. A lei britânica foi aprovada após uma década de debates envolvendo legislativo, governo, sociedade civil e comunidade científica, e após ter-se atacado a pergunta sobre o estatuto do embrião em seu estágio inicial. Seu texto final liberava a manipulação experimental de embriões in vitro até o limiar de 14 dias após a fertilização: marco daquilo que passou a configurar uma nova categoria classificatória, o "pré-embrião". Uma Autoridade nacional, controlada pelo Legislativo, foi instituída para proceder à supervisão e ao monitoramento das pesquisas em caráter permanente.

Em março de 2005, o Congresso Nacional brasileiro votou o texto final da nova Lei de Biossegurança que, além de regulamentar a pesquisa e a produção de organismos transgênicos, estabelecia as regras para o uso de embriões congelados na pesquisa com células-tronco embrionárias (CTEs) humanas. O texto original, concebido para abordar apenas os organismos transgênicos, passou a incluir o tema das células-tronco ao longo de sua tramitação como resultado da pressão dos lobbies interessados na aprovação das duas biotecnologias. Os dispositivos relativos à matéria, contidos no texto final — que liberavam o uso dos embriões excedentes congelados nas clínicas de reprodução assistida há mais de três anos - foram considerados regras provisórias, vigentes até que se acordasse uma nova legislação específica e ampla para a pesquisa com embriões humanos no país.

Os dois processos legislativos, separados por uma década e meia, à primeira vista guardam diferenças radicais. Os britânicos não só dedicaram um texto específico à pesquisa embriológica, como conduziram um debate longo e aprofundado que extrapolou os muros do Parlamento até que se 
chegasse a uma resposta (ainda que não unânime) à questão sobre seu estatuto. A regra brasileira para a pesquisa com os embriões congelados, por sua vez, mal pode ser chamada de "lei"; trata-se de um artigo "encaixado" em texto destinado a resolver a urgente polêmica dos transgênicos que foi açodadamente votado em poucos meses, com bem menos debate do que o tema mereceria.

Não obstante estas (importantes) diferenças, argumentarei aqui que os dois debates repousam sobre semelhanças fundamentais, que decerto não se limitam à questão dos embriões in vitro. Algumas delas compõem estruturas de longa duração da chamada "modernidade ocidental"; outras parecem emanar justamente do abalo a que vêm sendo submetidas tais estruturas. Este processo duplo e contraditório diz respeito, de modo central, à questão mais geral da redefinição política da natureza que vem se dando com os recentes avanços biotecnológicos. Apesar de os processos políticos que acontecem no âmbito dos Estados nacionais (como os analisados aqui) terem a vantagem de concentrar algumas das principais tensões ligadas às incertezas engendradas pela recente intensificação do progresso tecno(bio)científico, como vêm notando diversos estudiosos das novas biotecnologias (por exemplo, Strathern 1992; Rabinow 1999; Latour 1999), esta é uma política que transborda seus limites. Não obstante as diferentes feições atribuídas a tal "política", a convergência parece se dar no nível da própria definição da realidade, social ou natural — ou, para ser mais precisa, no nível da construção da partilha entre ambas. No caso dos embriões produzidos em laboratório e de sua manipulação experimental, o que está em jogo é uma redefinição das próprias fronteiras do humano - naquilo que temos de "natural" e de "cultural".

Neste sentido, a problemática do embrião ex utero insere-se, porém extrapola, o universo analítico da "noção de pessoa" - a partir do ponto em que o tema tem sido tratado, em grande medida, pela antropologia, em especial no âmbito dos estudos sobre o parentesco (Cannell 1990; Edwards et alii 1993; Salem 1997; Luna 2007). O problema maussiano, no entanto, refere-se essencialmente ao sujeito. Tais análises tendem, assim, a situar o embrião em termos da rede social mais próxima (mormente de parentesco) e de sua categorização enquanto "pessoa", em termos da qual ele pode aparecer ora como entidade individual, ora como emaranhado em uma teia de relações sociais (Luna 2007) — ou, ainda, a "explorar de que maneira a noção de indivíduo se imiscui no nosso modo de conceber o embrião" (Salem 1997:78).

No entanto, a tensão central que envolve a definição de regras para o uso do embrião na pesquisa científica diz antes respeito a se (ou quando) ele é sujeito humano ou não. Se ele resta no reino dos humanos plenos 
de direitos e dignidade ou se, ao contrário, é absolutamente objetificado, transferido para o reino da natureza não-humana. Neste caso, faz-se necessária, portanto, uma perspectiva que não parta de a prioris acerca do que seja humano e não-humano, sujeito ou objeto. A noção de "vínculo", avançada por Bruno Latour (2000b), aponta neste sentido ao postular que as entidades que compõem o mundo natural ou social não são essenciais, mas apenas "bem ou mal vinculadas": mais ou menos capazes de agenciar e multiplicar vínculos que as constituam (de forma sempre provisória). No caso do embrião ex utero, tais vínculos ainda são frouxos, caracterizando-o mais como um tipo de "vínculo de risco", ou seja, as redes sociotécnicas que os circundam são visíveis, assim como a incerteza acerca da hierarquia entre eles e outras entidades, explicita Latour (1999:40). Neste caso, as posições de sujeito/objeto não são dadas de antemão: são antes sujeitas a negociações políticas, num sentido estendido do termo, uma vez que desta feita trata-se de definir politicamente a própria ontologia natural.

A polêmica legislativa relativa à pesquisa com embriões humanos traz à tona o paradoxo moderno, destacado por Ingold (1994), segundo o qual os homens constituem uma espécie equivalente às outras (portanto, natural), ao mesmo tempo em que são dotados de uma condição moral oposta à animalidade. Os debates públicos em torno da pesquisa embriológica que proliferam pelo mundo parecem acontecer justamente neste interstício entre a humanidade e a não-humanidade (que decerto não se reduz à animalidade). Uma comparação entre eles — e/ou com debates correlatos (e anteriores), como o do aborto - poderia descortinar as continuidades e as descontinuidades entre essas múltiplas negociações biológicas/cosmológicas que vêm ocorrendo nas fronteiras do "humano".

Nas próximas seções, descreverei o mais extensamente possível os dois processos legislativos, o brasileiro e o britânico. A referência empírica para este último será a série de artigos de Michael Mulkay sobre o Human Fertilisation and Embriology Bill (projeto de lei que deu origem à legislação de 1990) publicados em revistas britânicas nos anos que se seguiram à aprovação da lei. Para o caso brasileiro, basearei a descrição em minha própria pesquisa documental sobre a tramitação do Projeto de Lei da Biossegurança no Congresso Nacional, que enfocou a participação dos cientistas no processo legislativo através de consulta a notas taquigráficas, documentos legislativos e jurídicos e material de imprensa. Todavia, em vista das limitações de espaço deste estudo, peço ao leitor que se refira às páginas indicadas em Cesarino (2006) para uma ancoragem etnográfica mais precisa. Em seguida, traçarei um quadro comparativo tendo como eixo a problemática do estatuto do embrião, mostrando quais foram as soluções a que chegaram 
ambos os Parlamentos para a questão do seu uso na pesquisa científica, e como o fizeram. Finalmente, à luz das considerações empíricas, discutirei como a antropologia pode contribuir para a compreensão das negociações contemporâneas em torno do estatuto do embrião e, portanto, do que seja o próprio "humano".

\section{O Human Fertilisation and Embriology Bill (HFEB)}

O Reino Unido foi pioneiro no estabelecimento de legislação específica para a pesquisa com embriões humanos, tornando-se um marco internacional de referência para processos legislativos subseqüentes (Plomer 2003), inclusive o brasileiro. A lei britânica constitui um caso polar, já tendo sido alvo de várias análises sociológicas e antropológicas. Entre elas, a série de artigos concatenados de Mulkay (muito mais descritivos que analíticos) constitui um excelente registro, que traz rico material empírico sobre a tramitação do projeto de lei no Parlamento britânico (Mulkay 1993, 1994a, 1994b, 1994c, 1994d, 1995a, 1995b, 1995c). ${ }^{1}$

O Human Fertilisation and Embriology Bill é fruto de um vácuo legal: aquele aberto pelo nascimento do primeiro bebê de proveta, em 1978. Tal evento engendrou, além de Louise Brown, uma entidade antes inexistente: o embrião fora do útero. $\mathrm{O}$ advento da fertilização in vitro e as potencialidades técnicas (terapêuticas, reprodutivas etc.) que ele descortinou, logo abriram um debate mundial sobre a necessidade de se imporem controles éticos às novas tecnologias de reprodução assistida - o que incluía, na pauta de deliberações, o tema do estatuto moral e jurídico do embrião produzido artificialmente. O projeto de lei britânico foi criado para abranger todo este amplo escopo de atividades: além da reprodução assistida, também a pesquisa embriológica e genética. Mas, como destacou especialmente Franklin (1999), o estatuto do embrião produzido em laboratório e os limites a serem impostos à sua manipulação logo passariam ao primeiro plano nos debates parlamentares.

Com vistas a agregar aportes para o debate legislativo nacional em torno do tema, o governo britânico estabeleceu, em 1982, uma Comissão mista presidida pela filósofa Mary Warnock e composta de 16 representantes das áreas científica, jurídica, assistência social, saúde, teologia e fundos beneficentes. Houve consenso entre seus membros a respeito de todas as 64 recomendações a serem feitas ao Parlamento, exceto uma: a pesquisa com embriões humanos. Em uma votação apertada, o relatório final da Comissão, o famoso Relatório Warnock, publicado em 1984, acabou por propor a permissão do uso, na pesquisa científica, de embriões produzidos artificialmente até 14 dias após a fertilização. ${ }^{2}$ 
As mesmas divergências em torno do tema observadas no âmbito da Comissão Warnock persistiram ao longo de todo o debate parlamentar subseqüente. A polaridade inicial foi tamanha que o governo resolveu adiar o envio de seu anteprojeto ao Parlamento para que pudesse estender o período de consulta. O texto do governo, publicado em fins de 1987, só foi enviado aos parlamentares em 1988, e expressava uma posição neutra: continha dois artigos alternativos referentes à pesquisa. Um deles seguia a recomendação da Comissão Warnock e liberava a manipulação experimental dos embriões de até 14 dias; o outro proibia e criminalizava o procedimento em qualquer estágio do desenvolvimento embrionário.

Os opositores ao uso dos embriões humanos na pesquisa, capitaneados pelo tradicional lobby antiaborto, iniciaram os debates no Parlamento em vantagem: na primeira apreciação das propostas contidas no Relatório Warnock em 1985, contabilizaram 51\% dos parlamentares trabalhistas e 88\% dos conservadores (Mulkay 1994b). O lobby pró-pesquisa, por sua vez, encontrava-se naquele momento fracamente organizado. Sua timidez era ainda maximizada pelas lacunas contidas no Relatório a respeito do estatuto do embrião: os membros da Comissão Warnock não apresentaram uma justificativa ontológica para o limiar dos 14 dias. Por outro lado, argumentos ontológicos abundavam do lado dos opositores à pesquisa com os embriões (aos quais chamavam "crianças não-nascidas"). Seus argumentos, herdados do discurso antiaborto, eram predominantemente calcados não em argumentos científicos, mas em "valores básicos", como o direito à vida, à dignidade humana, à proteção ao (embrião) inocente e à integridade da família. Tal (des)equilíbrio de forças chegou a instigar um membro da Câmara dos Lordes a apresentar projeto de lei banindo definitivamente a pesquisa com embriões no país, o qual recebeu então amplo apoio dos colegas parlamentares; porém, sem a participação ativa do governo em sua defesa, acabou não se transformando em lei.

Mas esta fase inicial de dura e ampla oposição à pesquisa com embriões durou apenas até 1986. Em fins de 1985, os cientistas defensores da pesquisa, apoiados pelos (ainda) poucos parlamentares simpáticos à causa, criaram um grupo de pressão denominado PROGRESS, que passou a coordenar uma ampla campanha junto à mídia e ao Parlamento. Através da difusão de uma imagem positiva da pesquisa com os embriões, calcada principalmente nos benefícios que ela traria ao controle das doenças genéticas, pretendiam atrair para seu lado a opinião pública em geral e, assim, aumentar seu poder de fogo dentro do Legislativo. O lobby pró-pesquisa ainda ganhou tempo para atuar com a extensão do período de consulta proposta pelo governo, que durou até o início de 1988, quando o anteprojeto foi enfim enviado para apreciação no 
Parlamento. Àquela altura, na mídia, a defesa da pesquisa já predominava, através da difusão de notícias, como os experimentos bem-sucedidos de prevenção da transmissão de certos tipos de doenças genéticas.

Além disso, com esse novo prazo, os defensores da pesquisa no Parlamento puderam pôr em ação outra de suas estratégias principais: tentar mudar a própria imagem do embrião que era apresentada por seus opositores. Dois anos após a edição do Relatório Warnock, a única embriologista da Comissão publicou uma carta na prestigiada revista Nature, destacando a inadequação do termo "embrião" utilizado no Relatório. Segundo ela, o que existiria antes do surgimento da linha primitiva no $14^{\circ}$ dia seria uma "massa de células gerada pelo ovo fertilizado"; apenas após 14 dias "pode-se dizer que começou o desenvolvimento embrionário individual" (McLaren apud Mulkay 1994a). Para designar o embrião neste estágio inicial, ela introduziu a categoria "pré-embrião" (McLaren 1986). ${ }^{3}$ O lobby pró-pesquisa passou a contar, a partir daí, com um vocabulário através do qual poderia argumentar no mesmo terreno da oposição: o do estatuto ontológico do embrião. A defesa da categoria pré-embrião valia-se de uma série de marcos morfológicos para instilar a idéia de que, até o $14^{\circ}$ dia, tratar-se-ia de uma "massa celular indiferenciada", da qual um indivíduo humano poderia ou não emergir (tais marcos serão explorados adiante).

Na apreciação do anteprojeto do governo, as comunidades médica e científica assumiram a linha de frente na difusão do novo conceito entre os parlamentares, empreendida através de um esforço amplo e intensivo:

[Os] parlamentares eram levados a laboratórios de pesquisa e clínicas de FIV, cientistas (assim como pacientes e médicos especialistas) faziam visitas repetidas ao Parlamento, e documentos informativos eram postos em circulação com regularidade [...] À medida que a palavra [pré-embrião] se difundia, o mesmo ocorria com o apoio parlamentar à pesquisa (Mulkay 1994a:627-8).

Como resultado, nas derradeiras etapas do debate parlamentar, o argumento a favor da pesquisa passou a contar com "um conteúdo embriológico detalhado" e "um vocabulário semitécnico agora bem maior" (:629). Aos poucos, o lobby pró-pesquisa logrou que o confronto passasse a se colocar entre "a retórica essencialmente moral dos opositores à pesquisa e a retórica semitécnica de seus defensores" (:631).

Um importante fator a animar tal movimento foi o contato direto entre parlamentares e cientistas, intensificado ao longo dos anos através de freqüentações recíprocas: os especialistas convidavam os representantes a realizar visitas guiadas aos laboratórios e às clínicas de reprodução assistida, 
enquanto faziam eles mesmos incursões regulares ao Parlamento. Outras frentes de convencimento foram o uso maciço da mídia visando ao apoio público à causa da pesquisa e a circulação de documentos trazendo atualizações sobre os últimos avanços técnicos na área (Mulkay 1994b).

Além dos próprios cientistas, representantes de outro grupo interessado na liberação da pesquisa com os embriões também travavam contato regular com os parlamentares: as vítimas de doenças genéticas e seus familiares. No auge de sua campanha pró-pesquisa, o PROGRESS chegou a organizar uma visita a Westminster de 200 famílias afetadas por doenças genéticas. Este afluxo de pessoas foi acompanhado por uma intensificação, no debate, dos argumentos a favor da pesquisa que se calcavam nos benefícios que ela traria à sociedade britânica. No Relatório Warnock, assim como nos primeiros momentos da tramitação do HFEB, tais benefícios diziam respeito principalmente ao combate à infertilidade (ou seja, à oportunidade de dar filhos àqueles que "naturalmente" não os teriam). Já nas fases mais avançadas do debate parlamentar, Mulkay (1994b) destacou justamente a retração deste argumento, e sua substituição pelo tema mais geral das doenças genéticas:

Durante os discursos pró-pesquisa nas fases mais avançadas do debate, o controle das doenças genéticas era com freqüência o foco central, e seus benefícios e procedimentos técnicos eram elaborados em detalhe. Nos debates conclusivos, o controle das doenças genéticas era o tópico dominante. Muitos parlamentares devotaram a maior parte de seus discursos a descrever os horrores da anormalidade congênita e a enfatizar o enorme incremento na felicidade humana que se daria com uma redução em sua freqüência (:203).

Assim, a ênfase nos benefícios a serem gerados pela pesquisa era acompanhada de uma exploração dos "horrores" das doenças a serem evitadas, reforçada ainda pela presença de suas vítimas no Parlamento, ou por testemunhos pessoais dos próprios parlamentares sobre casos semelhantes de familiares ou conhecidos.

Mas Mulkay ressalvou que tal controle genético, apesar de desejado, era também temido pelos parlamentares britânicos. Para muitos, ele concretizava os medos expressos na tese da "inclinação escorregadia", segundo a qual a pesquisa com embriões carrega consigo um risco iminente de transgressão das fronteiras morais mais básicas - rumo, por exemplo, à engenharia genética de seres humanos ou a um sistema reprodutivo "moralmente corrupto". Tanto que, no início dos debates, o tema do controle genético era utilizado como argumento contra a pesquisa, e não em seu 
favor, como tendeu a ocorrer nos estágios mais avançados da tramitação do HFEB. Havia, todavia, um consenso de que qualquer pesquisa deveria ser feita dentro de controles éticos estritos, e o anteprojeto de 1987 trazia importantes dispositivos neste sentido, como a instituição de uma agência para licenciar e monitorar as pesquisas em caráter permanente: a Human Fertilisation and Embriology Authority. Entre suas funções estava garantir que os laboratórios não cruzassem algumas destas fronteiras, ou seja, não conduzissem experimentos com embriões além dos 14 dias, e nem realizassem manipulação genética dos pré-embriões.

Em vista de tais receios, a estratégia dos cientistas britânicos passou a incluir um maior esclarecimento sobre os resultados precisos pretendidos pela pesquisa com os embriões. Um editorial da revista Nature, trazido por Mulkay (1994b:206), resumiu bem a convocação para esta força-tarefa: "O ingrediente que falta ao debate [tem sido] uma enunciação clara de quais exatamente são os benefícios das pesquisas com embriões humanos". Parte desta enunciação consistiu em ligar a prevenção dos defeitos genéticos às técnicas de seleção genética, e desvinculá-la da substituição de genes (o que seria visto como engenharia genética em seres humanos):

O benefício central a ser derivado da pesquisa com embriões era definido cuidadosamente como a capacidade de garantir que, em casos onde houvesse risco conhecido de defeito genético, apenas embriões saudáveis fossem implantados no útero da mãe. Este tipo de procedimento, enfatizava-se, não alterava a carga genética do embrião, e não deveria ser visto como uma interferência intrusiva na ordem natural, mas simplesmente como um modo de melhorar processos ineficientes de redução embrionária e seleção natural (Mulkay 1994b:206).

Pretendia-se, assim, aproximar a seleção genética de um procedimento "natural": no laboratório, o homem faria o mesmo que a natureza, só que de modo mais eficiente. ${ }^{4}$

Como efeito do sucesso desta série de estratégias práticas e discursivas, o lobby pró-pesquisa logrou que "a substituição do sujeito experimental violado pelo pré-embrião geneticamente filtrado [fizesse] a continuação [da pesquisa] parecer obrigatória" (Mulkay 1994a:633). A ênfase no controle genético foi o fator definitivo para consolidar a virada a favor da liberação da pesquisa no Parlamento britânico. Quase um quarto dos representantes que havia originalmente votado contra o Relatório Warnock acabou colocandose a favor da pesquisa com os (agora) pré-embriões na derradeira votação do projeto de lei em 1990, ao mesmo tempo em que não houve movimento algum no sentido contrário. 
Em síntese, portanto, as análises de Mulkay identificaram dois como os principais vetores a forçarem a inversão do equilíbrio na balança parlamentar em favor da aprovação da pesquisa: "o crescente uso do conceito de pré-embrião e a proeminência, nos argumentos dos apoiadores da pesquisa com os embriões, da idéia de que tal pesquisa levaria a um controle efetivo de uma ampla gama de doenças genéticas" (Mulkay 1994b:200), ou seja, os parlamentares britânicos que mudaram de lado o fizeram porque foram de fato convencidos pelos argumentos dos cientistas: suas "estimativas dos benefícios prováveis [da pesquisa], assim como sua representação do embrião" (Mulkay 1994b:200). Pode-se então dizer que tal virada, especialmente se comparada ao caso brasileiro que apresentarei adiante, deu-se em larga medida num plano conceitual: logrou-se emplacar uma nova categoria para delimitar o objeto passível de ser utilizado na pesquisa científica: o pré-embrião de até 14 dias.

\section{Projeto de Lei da Biossegurança (PLB)}

Os eventos que originalmente levaram à composição de uma nova regra para a biossegurança no Brasil nada tinham a ver com a pesquisa com embriões. A lei então vigente, datada de 1995, passou a ser objeto de uma série de contestações judiciais a partir de 1998, quando a Comissão Técnica Nacional de Biossegurança (CTNBio), instituída por ela para decidir sobre a segurança dos transgênicos a serem introduzidos no país, aprovou o pedido de comercialização da soja Roundup Ready feito pela multinacional agroquímica Monsanto. A partir daí, uma série de liminares na justiça passou a contestar tal parecer. Enquanto isso, no Rio Grande do Sul o plantio clandestino da semente geneticamente modificada disseminava-se a passos largos.

Tal situação de incerteza jurídica persistiu até a posse do novo governo, que decidiu então enviar ao Congresso Nacional um outro texto que contornasse as contradições contidas na lei anterior. Em fins de outubro de 2003, após nove meses de debate interno entre os ministérios do governo Lula interessados na questão, a Casa Civil encaminhou ao Congresso Nacional seu anteprojeto, que se restringia apenas à matéria dos transgênicos. Todavia, repetindo dispositivo contido na Lei de Biossegurança de 1995, ele trazia em seu artigo sexto a proibição de "produção, armazenamento ou manipulação de embriões humanos destinados a servir como material biológico disponível". Tal disposição, apesar de periférica no conjunto da legislação da biossegurança, abriu brecha para que um debate latente sobre a pesquisa com células-tronco embrionárias pudesse ser reavivado quando da introdução do projeto de lei no Congresso Nacional (Cesarino 2006:cap. 2). 
A tecnologia da produção de células-tronco para fins terapêuticos a partir de embriões humanos era um desenvolvimento bastante recente à época da elaboração do PLB: as primeiras células-tronco embrionárias humanas haviam sido isoladas e cultivadas em $1998 .{ }^{5}$ Desde 1999 , laboratórios brasileiros desenvolviam pesquisas com células-tronco adultas ${ }^{6} \mathrm{com}_{\text {resultados }}$ promissores em alguns campos, como no tratamento de cardiopatias e doenças auto-imunes, além de cirrose hepática e acidente vascular cerebral. ${ }^{7}$ Entretanto, parte da comunidade científica nacional estava desejosa de desenvolver experimentos, já adiantados em outros países, com células-tronco embrionárias humanas - aparentemente mais promissoras que as adultas devido ao seu suposto maior poder de diferenciação, porém mais problemáticas eticamente devido ao fato de sua retirada provocar a destruição do embrião. Mas no Brasil não havia, como não há, legislação federal específica regulando o uso de embriões humanos na pesquisa científica (e nem os procedimentos de reprodução assistida). O artigo sobre a manipulação dos embriões contido no esboço da Lei de Biossegurança foi visto, assim, como uma chance para introduzir tal regulamentação.

Logo que o texto do Executivo chegou à Câmara dos Deputados, o primeiro relator do projeto e então líder do governo na Casa, deputado Aldo Rebelo (PCdoB/SP), cedendo (sem resistência) a pressões dos grupos de interesse, retirou a vedação à manipulação dos embriões humanos contida no anteprojeto. No entanto, ao simplesmente retirar a vedação, o Substitutivo de Rebelo não especificava aquilo que seria permitido, o que deixava em aberto, inclusive, a possibilidade da produção de embriões exclusivamente para pesquisa, fosse através de fertilização in vitro, ou mesmo de clonagem.

A reação dos parlamentares chamados "cristãos", agrupados na Bancada Católica e na Frente Parlamentar Evangélica (FPE), foi imediata. ${ }^{8}$ Seu posicionamento contrário ao uso de embriões humanos na pesquisa científica baseava-se fundamentalmente na tese do início da vida com a fertilização do óvulo pelo espermatozóide, ou concepção. ${ }^{9}$ Tal posicionamento não era novo - a questão das células-tronco entrou num campo de debates parlamentares já conformado por anos de discussão sobre temas correlatos, como o aborto e a reprodução assistida (que decerto têm interseções não apenas práticas, mas também teóricas, com o tema da pesquisa embriológica). Os grupos religiosos, valendo-se de sua robustez política e numérica, evidente especialmente na Câmara dos Deputados, forçaram acordo com o relator seguinte do projeto, deputado Renildo Calheiros (PCdoB/PE), no sentido de modificar o texto de Rebelo. Insistindo no argumento de que sua posição expressava a vontade da maioria da população brasileira, eles ameaçaram colocar-se contra o seu relatório e mesmo contra o governo em 
outras votações, caso Calheiros não (re)incluísse a vedação e estabelecesse a criminalização da manipulação experimental de embriões humanos. A partir de então, a polêmica das células-tronco começou a tomar corpo no Congresso e foi aos poucos ultrapassando a dos transgênicos em termos de visibilidade na opinião pública; a ponto de, ao final, um projeto de lei concebido originalmente para resolver a urgente questão da soja transgênica sair do Congresso Nacional, dezessete meses depois, como a lei que liberava a pesquisa com embriões humanos no país!

Mas a definição do Parlamento sobre a questão dos embriões só viria a ter lugar na etapa seguinte da tramitação do PLB: o Senado Federal. Atropelado pela força e pela organização das bancadas cristãs na Câmara dos Deputados, o lobby pró-pesquisa aproveitou a mudança de fórum para articular-se no sentido de tentar reverter o quadro negativo cristalizado no Substitutivo de Calheiros. Seu esforço não poderia ser tímido: caso fosse modificado pelos senadores, o projeto ainda deveria voltar à Câmara para uma votação final. Além disso, alguns senadores ameaçavam dividir o texto em dois, para que transgênicos e células-tronco fossem tratados separadamente; sugeriam que estas últimas fossem incluídas em projeto de lei sobre a reprodução assistida que tramitava há alguns anos no Congresso. Tal manobra desagradaria ambos os lobbies, que imaginavam serem as duas tecnologias aprovadas mais facilmente caso uma "pegasse carona" com a outra: os defensores dos transgênicos porque a polêmica extrema envolvendo os embriões tendia a tirá-los de foco perante a opinião pública; os defensores da pesquisa com as CTEs porque desejavam aproveitar-se da extrema urgência que animava a tramitação da nova regra para os transgênicos (Cesarino 2006:59-60).

O lobby pró-pesquisa era composto principalmente por cientistas, de um lado, e grupos organizados de vítimas de doenças e deficiências potencialmente tratáveis através da terapia celular, de outro. Estas últimas foram estimadas, nos debates parlamentares, em milhões de brasileiros, uma vez que a gama de problemas abrangidos era imensa: iam de paralisias decorrentes de lesões físicas a males crônicos, como diabetes e câncer, passando por síndromes degenerativas, como Parkinson e Alzheimer, e doenças genéticas, como fibrose e atrofia espinhal. Entre os especialistas, havia dois com grande visibilidade pública na época: a diretora do Centro de Estudos do Genoma Humano da USP, dra. Mayana Zatz (também membro honorário da principal ONG de pacientes pró-pesquisa, o Movitae); e o oncologista, escritor, apresentador de tevê e "formador de opinião", dr. Dráuzio Varella.

O esforço de convencimento junto aos senadores deu-se, portanto, em duas frentes. Os pacientes, seus familiares e apoiadores valeram-se de uma 
série de argumentos especialmente direcionados aos políticos: além do já citado número de potenciais beneficiários (um contingente de eleitores nada desprezível), também lembraram que suas patologias eram um peso econômico e social considerável para o Estado, e que as pesquisas beneficiariam não apenas pessoas ou associações específicas, mas "uma população inteira", já que não é possível saber quem seriam os futuros portadores das doenças. Dessa forma, remetiam não só às vítimas já existentes, como às futuras, trazendo um benefício permanente à sociedade. Visitas organizadas ao Parlamento, especialmente nos dias de votação, além da emissão de cartas e manifestos e a apresentação de testemunhos, também foram estratégias bastante exploradas.

Já o poder de fogo dos cientistas concentrou-se em audiência pública realizada na Comissão de Assuntos Sociais do Senado Federal em 2 de junho de 2004, para a qual foram convidados a palestrar como especialistas (Cesarino 2006:cap. 4). ${ }^{10}$ Além de um bom contingente de senadores, a audiência contou com a presença de diversos líderes partidários de ambas as Casas do Congresso, além de ter sido transmitida pela TV Senado. Lá, decididos a "desmistificar" o tema, os experts procuraram colocar a audiência a par dos "detalhes técnicos" sobre a terapia com as células-tronco embrionárias. Diante da reação radicalmente negativa dos deputados à perspectiva de se produzirem embriões para a pesquisa, tal proposta nem chegou a ser incluída na pauta de negociações com os senadores. A ofensiva dos especialistas deu-se, antes, no sentido de tentar emplacar ao menos uma das duas alternativas restantes para a obtenção de células-tronco embrionárias que se encontravam então disponíveis: a chamada "clonagem terapêutica", e o aproveitamento dos embriões excedentes congelados nas clínicas de FIV. Diante da resposta mais positiva dos parlamentares à segunda opção, nela se concentraram. ${ }^{11}$

A argumentação dos cientistas em defesa da liberação para a pesquisa dos embriões supranumerários percorreu uma série de eixos. Em primeiro lugar, estimaram que haveria de 20 a 30 mil embriões congelados nas clínicas de reprodução assistida do país que não seriam utilizados no procedimento, ou por serem inviáveis para implantação, ou porque os genitores, já tendo sido bem-sucedidos no tratamento ou, ao contrário, desistido dele, não os queriam mais. Tal cifra seria, segundo os especialistas, suficiente para sustentar a pesquisa científica com as CTEs por até cinco anos. ${ }^{12}$ Lembraram ainda que as técnicas da medicina regenerativa eram passíveis de patenteamento e que, se os laboratórios nacionais não desenvolvessem pesquisa própria, o país correria o risco de "ficar para trás" na corrida biotecnológica, dependendo do pagamento de royalties pelo uso das novas tecnologias te- 
rapêuticas. Os principais prejudicados seriam, como sempre, os cidadãos mais pobres, sem recursos para se tratarem no exterior.

Mas ainda que a ênfase na terapia celular como uma questão de saúde pública (inclusive da saúde das finanças públicas) tivesse apelo junto aos políticos, o problema da ética intrínseca à pesquisa com embriões humanos não podia ser contornado. Após a derrota sumária na Câmara, concentrar-se num debate conceitual sobre o embrião, como aquele ocorrido no Reino Unido, parecia sem grandes perspectivas de sucesso para os cientistas brasileiros. ${ }^{13}$ A estratégia então foi entrar no terreno da argumentação pragmática, que gravitou essencialmente em torno de dois eixos: uma equação do tipo "lixo ou pesquisa", fundamentada num cenário de inevitabilidade do descarte dos embriões congelados; e outra do tipo "blastócitos ou doentes", fundamentada numa hierarquização implícita dos tipos de humanos.

Inicialmente, os especialistas buscaram garantir aos parlamentares que o descarte dos embriões excedentes congelados nas clínicas de reprodução assistida, embora eticamente condenado, era prática corriqueira, e mesmo inevitável. ${ }^{14}$ Sobre este fato consumado, erigiram um trade-off a ser resolvido pelos parlamentares: era preferível que tais embriões fossem "jogados no lixo" (seu "destino inexorável", caso fossem deixados nas clínicas) ou que tivessem um "destino mais nobre", ao serem utilizados para "salvar outras vidas" através da terapia com as células-tronco embrionárias?

Tal discurso era ainda reforçado pela repetida contraposição do blastócito às vítimas das doenças potencialmente tratáveis através da terapia celular. Com apoio visual e recurso a casos concretos, especialmente de crianças, os especialistas enfatizaram, de modo semelhante e talvez até mais incisivo que no caso britânico, os "horrores" de uma vida marcada por doenças e deficiências. A questão colocada aos senadores era se, diante das enormes promessas terapêuticas da medicina regenerativa, não valeria a pena, mesmo com toda a controvérsia ética envolvida, "desvincular" as células-tronco dos blastócitos e "vinculá-las" às crianças doentes.

A audiência de 2 de junho foi das mais concorridas, tendo a platéia permanecido até o final, quando a exaltação da argumentação dos cientistas foi geral: saíram todos convencidos não só da eticidade, mas da própria necessidade de se liberarem os embriões excedentes para a pesquisa com as células-tronco. Os dois Substitutivos do Senado ao texto da Câmara, de autoria de Osmar Dias (PDT/PR) e Ney Suassuna (PMDB/PB), incluíram em seu artigo $5^{\circ}$ a liberação, para uso na pesquisa científica, dos embriões: i) inviáveis para implantação, ou ii) congelados nas clínicas de FIV há mais de três anos ou que, já congelados na data de publicação da lei, após completarem três anos, não seriam utilizados no procedimento; e iii) mediante a permissão dos 
genitores. A comercialização deste material foi criminalizada com base na lei de doação de órgãos. O texto final, de autoria de Suassuna, foi aprovado em Plenário pelos senadores, por ampla maioria, em 6 de outubro de 2004.

De volta à Câmara dos Deputados, o PLB só voltou à pauta no ano seguinte. Após sua passagem pelo Senado, o quadro de forças no Congresso Nacional como um todo havia claramente se invertido. Àquela altura, até mesmo parte importante dos deputados cristãos, especialmente evangélicos, havia mudado seu posicionamento a respeito da pesquisa com os embriões, aceitando sua liberação nos moldes estabelecidos pelos senadores. Na votação final do projeto, em 2 de março de 2005, vítimas de doenças e deficiências, seus familiares e apoiadores encheram as galerias e mesmo os corredores do Plenário para pressionar de corpo presente pela aprovação do artigo $5^{\circ}$. Naquela noite, a cada vez que um parlamentar proferia um discurso um pouco mais enfático em defesa da pesquisa com os embriões, era ovacionado com entusiasmo pelas galerias lotadas. Os deputados cristãos que restaram contrários à pesquisa, visivelmente mais tímidos nesta votação, não deixaram de expressar firmemente sua posição. Todavia, na temática dos discursos, muitas vezes recheados de testemunhos pessoais, predominou o apelo ao desespero dos familiares dos doentes e a esperança e o alento que a pesquisa lhes traria. Desta vez, funcionou: em Destaque para Votação em Separado, o artigo $5^{\circ}$ foi mantido por 366 votos contra 59. Sancionada pelo Presidente Lula alguns meses depois, a nova legislação da biossegurança passou a ser identificada como Lei no 11.105, de 24 de março de 2005.

Um ponto a reter a respeito da norma brasileira e que a diferencia de imediato da legislação britânica é, portanto, que a entrada da polêmica das células-tronco no debate parlamentar do Projeto de Lei da Biossegurança nunca visou, na realidade, estabelecer uma normatização definitiva e geral para a pesquisa com embriões humanos. Foi, antes, uma resposta provisória a pressões de parte da comunidade científica e de grupos organizados de pacientes em defesa de uma técnica que começava a despontar como promissora. Mas mesmo este curto debate público, relativo à questão da pesquisa com embriões humanos no Brasil, deixa entrever alguns dos eixos de tensão também observados no caso britânico, embora ambos não tenham tido a mesma resolução. Vamos a eles, portanto.

\section{Comparação: HFEB vs. PLB}

Um primeiro paralelo que salta aos olhos em relação ao percurso dos dois textos legislativos é uma semelhança de direção (apesar da enorme diferença 
de "distância" percorrida). Neste sentido, a descrição de Michael Mulkay (1994a) das linhas gerais do debate britânico bem que poderia servir também ao caso brasileiro:

Embora a reação inicial dos parlamentares aos experimentos com embriões tenha sido predominantemente hostil, e embora uma resistência vigorosa à pesquisa com os embriões tenha persistido até o fim, o dispositivo [...] em favor da pesquisa foi aprovado em última instância em ambas as Casas do Parlamento com confortáveis maiorias (:614).

Em ambos os países, uma hostilidade feroz inicial foi cedendo lugar, ao longo do tempo (e da ação dos lobbies pró-pesquisa) a um reconhecimento da necessidade, e mesmo da inevitabilidade, de se liberar em alguma medida a pesquisa com embriões humanos. As polaridades que se desenharam também foram semelhantes: de um lado, a oposição à pesquisa capitaneada por parlamentares religiosos e grupos antiaborto; de outro, sua defesa liderada por parte importante da comunidade científica com o apoio de grupos organizados de prováveis beneficiários de eventuais e futuros avanços terapêuticos.

Além disso, nos dois processos legislativos, a atuação direta e incisiva dos especialistas foi central para a inversão do equilíbrio de forças. Dois enunciados de parlamentares (um lorde britânico e um senador brasileiro), que foram efetivamente convencidos pelos argumentos dos cientistas, expressaram bem sua eficácia em "dissipar as brumas" em torno do tema:

Devo confessar que, quando comecei a pensar na questão, achava-a extremamente nebulosa. À medida que se seguiam os relatórios, debates, substitutivos e audiências, as brumas dissiparam-se [...] através da cisão da palavra embrião em duas [...] Os especialistas que ouvi ao longo desses anos tornaram isto bem claro para mim [...] Estas pessoas humanas tornaram a distinção tão clara que o problema moral de manipular o embrião durante os 14 dias após a fertilização desapareceu. Como resultado da certeza absoluta que a opinião médica me deu, acho que não há problema moral (Lorde Henderson 15/01/88 apud Mulkay 1994a:630).

Tenho convivido muito com cientistas. Raramente vi cientistas que apresentassem com argumentos tão convincentes suas idéias. Em geral, terminam falando o que não entendemos e acabamos ficando com a mesma idéia de antes. Aqui tudo foi bem explicado e persuadiu aqueles que, talvez, nem estivessem convencidos [...] Parabéns [...] a cada um de vocês que nos deram muita luz sobre um assunto confuso, complicado, mas que para mim, hoje, está absolutamente claro (Senador Cristóvam Buarque 02/06/04 apud Cesarino 2006:143). 
Como também se nota nas falas dos parlamentares, uma diferença prática importante, e talvez definitiva, entre a tramitação dos dois projetos de lei foi o prazo para sua apreciação: numa, os representantes foram convencidos "ao longo desses anos", e noutra, "aqui", em uma audiência pública. No Reino Unido, no decorrer de quase uma década, os discursos e as oposições foram se desenhando de modo gradual; houve tempo para redefinir categorias, para estabelecer uma nova linguagem provida pela ciência, que passou a delimitar os termos do debate parlamentar. O embrião gerado a partir da fertilização pôde ser repensado em termos de um divisor: o surgimento da linha primitiva -até quando ele configuraria uma entidade diferente, o "pré-embrião". Os especialistas britânicos lograram assim erigir de fato uma nova fronteira categórica ao delimitarem o objeto a ser usado de modo legítimo na pesquisa científica.

Já no caso brasileiro, a tramitação do PL da Biossegurança - não só pela questão das células-tronco, mas principalmente pela dos transgênicos deu-se sob o signo da urgência; houve tempo apenas para uma inversão pragmática, como a operada pelos especialistas na audiência pública no Senado. Além disso, os cientistas brasileiros apareceram menos como representantes de uma entidade biologicamente circunscrita do que como fiadores dos benefícios terapêuticos a serem trazidos pela pesquisa com essas entidades (embora, como se viu, os experts britânicos também tenham exercido este papel). A questão, todavia, fica: houvesse usufruído de um tempo maior como no Reino Unido, teria o lobby pró-pesquisa no Brasil logrado estabelecer um marco permanente para a pesquisa com embriões humanos no país?

O mesmo vale para os lobbies pró-pesquisa. No Brasil não houve um movimento amplo como o PROGRESS, mas ações pontuais (embora não menos eficazes) de alguns indivíduos junto à mídia e à opinião pública. A participação dos grupos organizados de pacientes também foi central em ambos os casos: a importância de tais atores crescia, como se viu, na proporção da exploração dos benefícios da pesquisa com os embriões nos respectivos debates parlamentares.

Outro eixo de comparação diz respeito ao próprio objeto do debate parlamentar: o que se debateu em ambos os casos? Conforme mostrou Mulkay, no Reino Unido assim como no Brasil, as divergências iniciais gravitaram de fato em torno das diferentes "concepções ou imagens do embrião" e das "interpretações das relações entre os embriões e os seres humanos plenamente desenvolvidos" (1994a:614). Apesar de o Relatório Warnock haver se esquivado com a justificativa de que quaisquer respostas à questão do estatuto do embrião seriam "complexos amálgamas de julgamentos factuais 
e morais" (apud Mulkay 1994a:616), tal argumentação não foi aceita pelos parlamentares britânicos, que tomaram a pergunta conceitual "o que é o embrião?" como foco central de seus debates. No caso brasileiro, por sua vez, ela foi pouco a pouco abandonada, para ser substituída pela questão pragmática: "o que fazer com os embriões excedentes congelados nas clínicas de reprodução assistida?".

Já em se tratando dos termos do debate, os dois casos parecem novamente se aproximar. Os discursos que largaram na frente nos dois países baseavam-se fundamentalmente em argumentos ligados a valores, éticos ou religiosos, contra a pesquisa com o embrião humano. No entanto, seus oponentes, liderados pelos cientistas, foram assumindo a dianteira, impulsionados em larga medida pela exploração de argumentação e vocabulário científicos em favor da pesquisa. Assim, aos poucos, um debate inicialmente conformado pelos problemas éticos do uso experimental de embriões humanos foi se transfigurando num embate entre o jargão técnico dos defensores da pesquisa e a retórica moral de seus contendores. Parte da eficácia dos lobbies pró-pesquisa em ambos os casos (e mais no britânico) tem a ver com esta redefinição dos termos do debate parlamentar sobre o embrião. Nestes casos, além disso, os oponentes à pesquisa eram freqüentemente qualificados por seus contendores como "obscurantistas", obstáculos à marcha do progresso. No caso do uso experimental de embriões humanos, esta tendência é ainda acentuada pela virtual onipresença de grupos religiosos cristãos como líderes da resistência contra a pesquisa, os quais foram associados, com freqüência, por seus defensores às práticas medievais da Inquisição (Cesarino 2006; Mulkay 1995b).

Outro paralelo que também pode ser traçado diz respeito aos controles que foram estabelecidos nos dois textos legislativos. No caso brasileiro, tais controles estão evidentes na transitoriedade mesma da legislação aprovada, bem como na criminalização dos procedimentos que fugirem à regra estabelecida. No caso britânico, a liberação dos embriões, embora ampla, não foi irrestrita: até os 14 dias, e sob rigorosas diretrizes éticas. O Parlamento britânico avocou para si o controle formal das políticas no setor ao reter a prerrogativa única de autorizar alterações nas diretrizes da Human Fertilisation and Embriology Authority. Contra a tese da "inclinação escorregadia", os defensores da pesquisa argumentaram que se um dia os princípios éticos precisarem ser modificados (como no caso da extensão do prazo para além dos 14 dias), a decisão última ficará com o Parlamento, e não com os cientistas (Mulkay 1994b:208).

Tais controles dizem respeito efetivamente à ambigüidade que carrega a intensificação do progresso tecnocientífico: ao mesmo tempo em que sus- 
citam esperança, instigam medo (cf. Mulkay 1993; Cesarino 2006:cap. 5). Isto porque a ciência traz, junto com os benefícios dos avanços tecnológicos, incertezas cada vez maiores sobre sua capacidade de controlar, ou prever, os efeitos de tais avanços. Ampla literatura aborda a questão do "risco" na contemporaneidade. ${ }^{15}$ No universo da regulamentação estatal da pesquisa biotecnológica, estas incertezas têm como efeito, como destacou Latour (1999), uma hibridização da representação: representantes epistemológicos (dos não-humanos, que lidam com fatos) passam a dividir com representantes políticos (dos humanos, que lidam com valores) a tarefa de definir as fronteiras do mundo natural.

No caso da pesquisa com embriões humanos, tal tarefa implica responder, ou ao menos aproximar, a pergunta sobre seu estatuto. Como o próprio Relatório Warnock reconheceu, a busca de tal resposta inevitavelmente tomará a forma de um "processo cindido" (Strathern 1992:142), no qual fatos biológicos e interpretações sociais desses fatos se alternariam, determinando-se reciprocamente sem no entanto se confundirem. Formariam como que um "híbrido conceitual: o caráter de uma entidade (informação biológica sobre células humanas) modificado pelo caráter de outra (debate ético sobre o tratamento de pessoas)". Como notou a autora a respeito da lei britânica, a ciência não tem a necessidade, por si, de definir um marco para o início da vida humana individual: "A biologia não nos diz que uma linha deve ou não ser traçada. É tarefa da legislação traçar as linhas" (:118). Mas os cientistas, quando chamados a tomar parte no debate público sobre a regulamentação de suas atividades de pesquisa, são forçados a introduzir um marco discreto no processo contínuo que é a vida biológica. Qualquer norma para a pesquisa com embriões humanos inevitavelmente pressupõe esta definição de uma entidade discreta: seja para constituir um objeto passível de uso em pesquisa ou, ao contrário, um sujeito com direitos de proteção pelo Estado. Como resultado, as diferentes teses científicas para o início da vida que apareceram nos debates parlamentares acabam trazendo a dualidade entre fatos e valores de que falou Strathern. No quadro a seguir, encontramse sistematizadas aquelas que identifiquei como as propostas apresentadas com maior freqüência na arena pública sobre o estatuto do embrião.

Não obstante a cientificidade das definições biológicas acima apresentadas, qualquer antropólogo é capaz de nelas discernir com facilidade uma série de traços cosmológicos definidores do "indivíduo moderno": a racionalidade (na tese neurológica), a in-dividualidade (na tese embriológica), a identidade (na tese genética) e a autonomia (na tese ecológica). No caso da tese gradualista, Strathern (1992:123-4) identificou a ressonância da concepção ocidental segundo a qual "as relações [são] posteriores à con- 
Quadro 1 - Diferentes teses científicas para o início da vida apresentadas na arena pública (Cesarino 2006:149)*

\begin{tabular}{|c|c|c|}
\hline Tese & Marco Inicial & Fundamentos Biológicos \\
\hline Genética & $\begin{array}{l}\text { Fertilização - encontro do } \\
\text { óvulo com o espermato- } \\
\text { zóide. }\end{array}$ & $\begin{array}{l}\text { Com a fecundação, há a formação } \\
\text { de estrutura celular com código } \\
\text { genético único. }\end{array}$ \\
\hline Embriológica & $\begin{array}{l}14^{\circ} \text { dia - completa-se a ni- } \\
\text { dação (fixação do embrião } \\
\text { na parede do útero) e a } \\
\text { formação da linha primitiva } \\
\text { (estrutura que dará origem } \\
\text { à coluna vertebral). }\end{array}$ & $\begin{array}{l}\text { O embrião configura-se como estru- } \\
\text { tura propriamente individual: não } \\
\text { pode se dividir em dois ou mais, nem } \\
\text { se fundir com outro. Além disso, dife- } \\
\text { rencia-se das estruturas celulares que } \\
\text { formarão os anexos embrionários. }\end{array}$ \\
\hline \multirow[t]{2}{*}{ Neurológica } & $\begin{array}{l}8^{a} \text { semana - aparecimento } \\
\text { das primeiras estruturas } \\
\text { que darão origem ao siste- } \\
\text { ma nervoso central (SNC). }\end{array}$ & \multirow{2}{*}{$\begin{array}{l}\text { Baseada no mesmo argumento da } \\
\text { morte cerebral: assim como a vida } \\
\text { só termina com a parada dos sinais } \\
\text { neurológicos, ela começa com o apa- } \\
\text { recimento das estruturas nervosas } \\
\text { e/ou de seus sinais. }\end{array}$} \\
\hline & $\begin{array}{l}20^{\mathrm{a}} \text { semana - completa a } \\
\text { formação do SNC per se. }\end{array}$ & \\
\hline Ecológica & $\begin{array}{l}\text { Entre a } 20^{\mathrm{a}} \text { ea } 24^{\mathrm{a}} \text { semanas- } \\
\text { completa a formação dos } \\
\text { pulmões, última estrutura } \\
\text { vital a ficar pronta. }\end{array}$ & $\begin{array}{l}\text { Principal fundamentação da decisão } \\
\text { da Suprema Corte norte-americana } \\
\text { autorizando o aborto, refere-se à capa- } \\
\text { cidade potencial do feto de sobreviver } \\
\text { autonomamente fora do útero. }\end{array}$ \\
\hline Gradualista & Não há. & $\begin{array}{l}\text { Supõe a continuidade do processo } \\
\text { biológico, no qual a vida é concebi- } \\
\text { da como um ciclo. Neste sentido, a } \\
\text { formação de um indivíduo começa } \\
\text { com a dos gametas de seus pais } \\
\text { ainda no útero das avós. }\end{array}$ \\
\hline
\end{tabular}

* É claro que não contemplei aqui toda a controvérsia e a especificidade que animam o debate sobre o início da vida no seio da própria comunidade científica - o que provavelmente multiplicaria e complexificaria ainda mais a categorização trazida. 
dição de pessoa do indivíduo, e não integrantes dela" na dupla orientação atribuída ao desenvolvimento embrionário: a um tempo genética (através de uma programação cromossômica "dada") e epigenética (através da interação com o ambiente). Entre carga genética e ambiente dar-se-ia o mesmo que entre indivíduo e sociedade: uma relação entre termos substancializados de antemão. A dualidade entre as âncoras morais e as biológicas de que fala a autora parece, assim, ser constitutiva de tais propostas sobre o estatuto do embrião - ao menos quando apresentadas na arena pública.

No debate britânico, o lobby pró-pesquisa claramente optou por uma destas teses, enquanto as demais foram obscurecidas. A principal força da tese dos 14 dias repousa em que este prazo coincide com a finalização de uma série de processos morfológicos que sustentam bem o argumento de que apenas a partir daí ter-se-ia de fato a vida humana individual (ou seja, in-divisível): aparece a linha primitiva, estrutura que virá a originar a coluna vertebral; o embrião não pode mais se dividir nem fundir-se; o conjunto celular que formará o feto separa-se das células que comporão os chamados "anexos embrionários" (placenta, cordão umbilical e demais estruturas de apoio); antes disso, as células são indiferenciadas internamente. A agregação deste conjunto de "fatos" na nova categoria "pré-embrião" permitiu assim "remover o objeto da experimentação científica do escopo do discurso moral" (Mulkay 1994a:631), e inseri-lo num universo "técnico". ${ }^{16}$

Neste ponto, os debates britânico e brasileiro parecem novamente divergir. Não que no caso brasileiro não houvesse referências continuadas a fatos biológicos; mas estas se davam normalmente de modo assistemático através da exploração ad hoc de uma ou outra tese para o início da vida, de acordo com a conveniência. Por outro lado, o discurso mais coerente e bem-sucedido dos cientistas brasileiros deu-se em bases predominantemente "valorativas" (ou hierárquicas), enfocando, como se viu, os indivíduos doentes e/ou deficientes em contraposição ao blastócito, caracterizado como "massa disforme". Houve também esforços criativos, e não menos eficazes, de unir, na mesma argumentação, ambas as âncoras ontológicas: a dos fatos e a dos valores.

Muitos cientistas acham que a vida não tem um começo nem um fim, que a vida é um ciclo. Então [...] se deixarmos o embrião congelado num centro de fertilização, se não usarmos esse embrião, o ciclo se interrompe. Se usarmos as células desse embrião para salvar uma vida, estamos retomando o ciclo da vida (dra. Mayana Zatz 02/06/04 apud Cesarino 2006:148).

É como se os britânicos, dentro do contínuo híbrido de que falou Strathern (1992), se situassem mais do lado dos "fatos" que os brasileiros — mas 
com os dois debates legislativos mantendo o caráter de "processo cindido" destacado pela autora.

Porém, não obstante os parlamentares brasileiros terem tentado contornar o debate conceitual, ao optarem pelos doentes e/ou deficientes em detrimento do blastócito, a questão sobre seu estatuto resta latente (ou, antes, pendente): trata-se, enfim, de um meio (sujeito) ou de um fim (objeto)? Afinal, ao ser destruído na pesquisa, o embrião de cinco dias passa ao outro lado do limiar ético kantiano, segundo o qual o ser humano nunca deve ser utilizado como meio (Kant 1986 [1785]); deixa de ser um indivíduo "fim em si" (Dumont 2001) e adentra, sub-repticiamente, na categoria de objeto. Sub-repticiamente porque, diferente do caso britânico, os parlamentares brasileiros não conceberam o blastócito categoricamente como objeto; ele apareceu mais como "uma vida que vale a pena sacrificar em prol de outras vidas". Ao invés de efetuar um corte, que jogaria o embrião em seu estágio inicial para o reino dos "não-humanos", estabeleceu-se antes uma hierarquia entre os humanos: entre aqueles não-nascidos, ocupando patamar mais inferior quanto menor seu grau de desenvolvimento embrionário; e aqueles nascidos, ocupando patamar mais superior quanto maior seu grau de "normalidade".

Convém não esquecer esta segunda hierarquização implícita entre os humanos normais e os doentes e/ou deficientes: o objetivo central da medicina regenerativa não é "compensar" deficiências através de uma ortopedia, mas efetivamente curá-las elevando o corpo com algum déficit a um grau máximo de "completude". Pode-se dizer que o espectro hierárquico, neste caso, é o mesmo tanto para os nascituros como para os nascidos: orienta-se no sentido de implementos de completude e eficácia funcional. A hierarquização aqui parece funcionar de modo análogo à do modelo dumontiano (Dumont 2001), no qual os diferentes termos não se situam em relação de exclusão, mas de englobamento: o todo é o "humano" (ou a "vida humana") no caso das sociedades modernas, idealmente equacionado ao "indivíduo enquanto valor". Este todo, por sua vez, engloba as partes que são os diferentes tipos concretos de indivíduo, todos eles humanos, porém dispostos em uma gradação hierárquica: o blastócito, o feto, a criança doente e/ou deficiente, a criança normal, o adulto doente e/ou deficiente e - no ápice o adulto normal (provavelmente também homem, branco, heterossexual e burguês).

Tal movimento, cabe lembrar, não é exclusivo do caso brasileiro: como se viu a respeito do controle genético, ele também apareceu entre os britânicos. Em ambos os casos, a explicitação deste espectro hierárquico parece denunciar não uma estrutura estanque (tal qual o individualismo enquanto ideologia aparece à primeira vista), mas algo mais nos moldes do 
"reordenamento das hierarquias" de que falou Latour (1999) (decerto não no sentido dumontiano do termo) a propósito dos vínculos de risco. Como o embrião ex utero ainda não é uma entidade "estabilizada", ou seja, dotada de essência ontológica definida, suas posições relativas na hierarquia da própria "humanidade" — enquanto espécie biológica e condição moral — são incertas e sujeitas a negociações expressamente políticas. Resta perguntar: empiricamente, em que sentido elas vêm se dando?

Os casos trazidos aqui mostraram que a moeda mais valorizada em tal negociação, e que passa a constituir em larga medida a pedra de toque do "reordenamento das hierarquias" em torno do embrião - o que também implica, no caso da pesquisa, um reordenamento das prescrições éticas correspondentes - foi fundamentalmente a mesma: os benefícios a serem providos pela pesquisa com os embriões, "garantidos" pela fé, por vezes cega a riscos, no progresso tecnocientífico.

\section{Os benefícios da pesquisa e a fé no progresso tecnocientífico}

Apesar de as células-tronco não terem sido uma questão para os britânicos à época dos debates em torno do $\mathrm{HFEB},{ }^{17}$ os benefícios, concretos ou virtuais, a serem obtidos a partir da manipulação experimental dos embriões produzidos através da FIV não ocuparam papel secundário. No Relatório Warnock, assim como em sua recepção pelo Parlamento, tais benefícios diziam respeito principalmente ao tratamento da infertilidade. Para os opositores à pesquisa que, lembremos, começaram vencedores - tal objetivo era considerado relativamente trivial por concernir um número pequeno de cidadãos, não compensando as dificuldades morais que teriam que ser contornadas, e nem mesmo o gasto de dinheiro público com a pesquisa. Todavia, ao longo dos debates assumiu o primeiro plano a "promessa mais recente do controle eficaz da transmissão de anormalidades genéticas" através de sua detecção ainda no estágio pré-embrionário (Mulkay 1994b:200). Transformados em questão de "saúde pública", tais benefícios passaram a dizer respeito à sociedade britânica como um todo: a implantação apenas dos embriões "normais" poderia prevenir o nascimento de crianças deficientes, poupando assim ao Estado e à sociedade seu "peso" social e econômico. A semelhança com linhas de argumentação pró-pesquisa no caso brasileiro das células-tronco não pára por aí:

À medida que o debate parlamentar adentrava sua fase conclusiva, as referências às "indefesas crianças não-nascidas" tornaram-se muito menos freqüentes. Em seu lugar, apareciam crianças miraculosamente saudáveis a serem produzi- 
das através das futuras técnicas que seriam a seu tempo derivadas da pesquisa com os pré-embriões (Mulkay 1994a:633).

A imagem de crianças doentes e/ou deficientes sendo salvas através das "futuras técnicas que seriam a seu tempo derivadas da pesquisa" foi moeda corrente, e altamente valorizada, em ambos os debates. A diferença é que, no caso britânico, os problemas seriam evitados ainda antes de o embrião ser implantado; as crianças, portanto, já nascerão saudáveis. No caso brasileiro, as crianças, tendo nascido deficientes, tornar-se-ão saudáveis através da terapia celular (na realidade, a terapia com as células-tronco embrionárias viria a ser uma dessas técnicas desenvolvidas a partir da pesquisa pioneira com embriões humanos). Uma outra semelhança marcante relativa aos benefícios da pesquisa reflete-se nos testemunhos pessoais dos parlamentares. A existência de familiares, especialmente filhos, doentes e/ou deficientes foi bastante evocada como justificativa para o voto favorável à pesquisa em ambos os casos (para exemplos etnográficos, cf. Cesarino 2006 e Mulkay 1994b). Ao menos no caso brasileiro, tais testemunhos foram capitalizados pelos próprios cientistas, que lançavam continuamente aos parlamentares a pergunta: "E se fosse com você? E se fosse com seu filho?".

Mas é interessante notar como nos dois casos, apesar da distância temporal, os benefícios da pesquisa genética, de um lado, e da terapia celular, de outro, eram basicamente virtuais. Tratava-se de promessas, dada a incipiência da pesquisa nas duas fronteiras terapêuticas em suas respectivas épocas. A adesão dos parlamentares aos argumentos dos cientistas derivou em grande medida, portanto, de uma "fé na capacidade dos cientistas de proverem esses futuros benefícios" (Mulkay 1994b:201). Sua força persuasiva foi tamanha que, no caso britânico, eles "conseguiram afastar os medos dos leigos acerca da possibilidade de a ciência perder o controle e promover uma atmosfera de esperança baseada na expectativa dos extraordinários benefícios que ainda viriam" (:209). No caso brasileiro, parte da oposição no Congresso deu-se entre aqueles que exploravam a terapia com as CTEs como a única "luz no fim do túnel" para pacientes já desenganados, e aqueles que denunciavam tal excesso de expectativas como "falsas promessas" (Cesarino 2006:153-157). A fé no progresso da ciência não serviu apenas para "garantir" os benefícios vindouros; também foi capaz de aplacar os medos de riscos futuros através da crença de que a própria ciência é capaz de prover as soluções para os males que cria.

Quais as conseqüências da convicção, que passou a ser amplamente compartilhada por cientistas e parlamentares ao final dos dois processos legislativos (e que, a esta altura, não parecem tão diferentes assim), de que 
a pesquisa com os embriões humanos eventualmente proveria os benefícios prometidos devendo, por isso, ser em alguma medida liberada?

Apesar de o Relatório da Comissão Warnock não ter trazido uma justificativa definitiva para o marco dos 14 dias sob o argumento de que qualquer uma consistiria em um "complexo amálgama de fatos e valores", algumas de suas passagens deixam entrever uma outra resposta ou, antes, um outro modo de responder à questão do estatuto do embrião:

Observamos que a posição mais comum, todavia, é que embora o embrião humano mereça algum grau adicional de respeito para além daquele concedido a outros sujeitos animais, este respeito não pode ser absoluto, devendo ser pesado contra os benefícios engendrados pela pesquisa (Warnock Report apud Mulkay 1994a:617).

As palavras do senador Tasso Jereissati (PSDB/CE) na audiência pública de 2 de junho parecem denunciar um passo na mesma direção:

Duvido que alguém que tenha algum contato com uma criança com problemas genéticos que possam ser resolvidos algum dia somente por meio desse desenvolvimento, duvido que alguém, sendo de qualquer religião, tenha qualquer dúvida sobre o caráter ético desse desenvolvimento científico (apud Cesarino 2006:177).

Em ambos os casos, está claro, os benefícios a serem derivados a partir da manipulação experimental dos embriões entram na conta da definição de seu estatuto e, portanto, do debate sobre a ética deste tipo de pesquisas. A qualidade ontológica da entidade que é o embrião fora do útero não é, assim, absoluta, um algo-em-si. Ele aparece novamente, nas palavras de Salem (1997), como um "entre" ou, poderíamos ainda dizer valendo-nos do vocabulário latouriano, como um "vínculo de risco" (Latour 1999). São os vínculos dos embriões com as vítimas das doenças genéticas e seus familiares, com seus representantes políticos e mesmo com os royalties a serem pagos pela técnica terapêutica que os utiliza como meio que conformarão suas fronteiras ontológicas.

A utilidade aparece assim como o principal ponto em comum, não obstante as diferenças entre as normas estabelecidas pelos dois parlamentos. Ela é a propiciadora dos vínculos mais fortes a se ligarem aos embriões; definições científicas e morais atribuídas a priori não foram suficientes para determinar o seu estatuto - mesmo porque estas estavam longe de ser consensuais. No acordo tecido entre religiosos e cientistas pelos senadores 
brasileiros em torno do artigo $5^{\circ}$, este apareceu como o único eixo de diálogo possível. E mesmo no caso britânico, a virada aparentemente conceitual incorpora os traços pragmáticos típicos do debate brasileiro: um pragmatismo que, fundado na utilidade, vem sustentar duplamente a ontologia e a ética da nova entidade que é o embrião produzido no laboratório - ao menos no que concerne ao seu uso na pesquisa com fins terapêuticos. Neste contexto, pode-se perguntar, como já fiz em outra ocasião inclusive com respeito aos transgênicos (Cesarino 2006) se, com a intensificação das revoluções biotécnicas recentes - como a engenharia genética, a terapia gênica e a medicina regenerativa - não se estaria consolidando, nas sociedades fundadas na tecnociência, uma ética de bases utilitárias.

Uma perspectiva ética neste sentido já foi em algum grau sistematizada conceitualmente na literatura especializada sobre bioética, muito embora referências a tais reflexões não tenham sido registradas na empiria aqui abordada (ao menos não através das fontes consultadas). De modo geral, a abordagem utilitarista prescreve que um curso ético de ação deva ser definido levando-se em conta seus resultados práticos e o quantum (positivo) de felicidade e (negativo) de sofrimento que poderia ser derivado, e não em obediência a princípios morais preestabelecidos. ${ }^{18}$ À antropologia pode caber a tarefa de descortinar empírica e comparativamente os elementos do sucesso prático de tal perspectiva. Um bom exemplo de empreendimento neste sentido é a breve "arqueologia" do utilitarismo no Ocidente feita por Marshall Sahlins (2003 [1996]). Outro seria refletir sobre o alcance atual e futuro do utilitarismo nas sociedades modernas: questionar, por exemplo, se tal ética aplicada aos avanços biotecnológicos não estaria denunciando a possibilidade da emergência de uma nova ontologia natural, também fundada na utilidade. Diante do que foi visto aqui, já seria possível sugerir que tal "utilidade" vai além (ou está aquém) da prescrição clássica da ciência como promoção do "bem comum"; parece ter mais a ver com a gradual abertura contemporânea à possibilidade do patenteamento de (e cobrança de royalties sobre) novas formas de vida e técnicas que operam no nível molecular. Mas esta é uma hipótese a ser desenvolvida empiricamente.

Nos casos brasileiro e britânico aqui analisados, a importância assumida por benefícios que são fundamentalmente virtuais ressalta ainda a persistente centralidade cosmológica de um dos pilares iluministas da modernidade: a fé na inexorabilidade do progresso tecnocientífico. Como notou Mulkay (1994b:200), parlamentares britânicos originalmente contrários à pesquisa passaram a ver "o desenvolvimento deste ramo de investigação científica como inevitável, infringindo ou não [os] valores morais estabelecidos": "não é possível atrasar o relógio"; "não podemos desfazer o iluminismo"; "não há 
caminho de volta" - foram alguns dos enunciados trazidos pelo autor. Em Cesarino (2006), também aparecem várias passagens análogas nos discursos dos parlamentares brasileiros: "podemos atrasar o progresso científico, mas é impossível impedi-lo"; " aquilo que tem de ser será"; " não podemos voltar atrás, pois a flecha está lançada". A este cenário de inevitabilidade, muitas vezes sustentado por fatos consumados (Cesarino 2006:185), corresponde uma confiança na capacidade da ciência não só de prover os benefícios prometidos, mas de aplacar seus males não-pretendidos (Beck 2003).

\section{Considerações conclusivas}

A partir do que foi visto, resta perguntar se tal abertura à utilidade não seria uma das contrapartidas do duplo processo no qual a ciência enquanto meio exclusivo de acesso ao mundo natural dos modernos vem sendo colocada em questão (Latour 1999), ao mesmo tempo em que a estrutura iluminista de longa duração, que é a crença no progresso da ciência, mantém-se, desta feita, sustentada pelos benefícios virtuais prometidos pelos avanços tecnológicos (Beck 2003; Cesarino 2006).

Sarah Franklin (1993) sugere que tais "abalos cosmológicos" são mais pronunciados em contextos como o das novas biotecnologias, nos quais a natureza é "assistida" ou aperfeiçoada. Ao fazer referência ao debate do HFEB, a autora destacou que a natureza, onde "falha", "torna-se uma autoridade mediada, um fundamento parcial, e passa então a precisar de 'assistência' por parte da lei para confirmar sua certeza" (:135-6); ou seja, a natureza pode ser melhor vista como construída justamente onde ela aparece como insuficiente do ponto de vista dos humanos e de sua utilidade (ou de seus riscos) para eles. Está claro que este gradiente de utilidade acompanha o próprio desenvolvimento científico: antes de se "descobrirem" as célulastronco não havia a necessidade delas para tratar determinadas doenças; antes de se "descobrir" o DNA recombinante não havia a necessidade dos organismos geneticamente modificados. Uma vez concretizados tais avanços técnicos, estas novas entidades passam a fazer parte da agenda científica e, assim, da própria configuração do mundo natural. Mas, desta vez, para que elas proliferem, precisam entrar também na agenda legislativa e submeterse a um processo decisório explicitamente político (Latour 1999). Nestes casos, as fronteiras do mundo natural não aparecem como dadas, podendo ser amplamente negociadas por outros atores que não seus representantes "oficiais", os cientistas - e efetivamente o são, inclusive em arenas decisórias institucionais como os legislativos nacionais, conforme vimos aqui. 
No caso específico da problemática do embrião que emerge com o advento das técnicas de fertilização in vitro, o pano de fundo remete diretamente à ambigüidade difundida entre os modernos em que "tanto a condição moral como o táxon biológico unem-se sob a rubrica única da humanidade" (Ingold 1994:6). No segundo caso, o homem é tipicamente objeto da biologia; no primeiro, das ciências humanas. A antropologia, em sua contribuição particular para a compreensão do "homem" em sua totalidade, tem a vocação, talvez única, de sobrevoar a interface entre estas duas províncias ontológicas que lhe são constitutivas - ou, antes, vê-las como um todo.

Quando se trata da manipulação experimental do embrião humano, a própria noção de indivíduo, típica dos estudos antropológicos da "pessoa", é problematizada: o quadro evidente de "crise de objetividade" que caracteriza os debates em torno de seu estatuto faz aparecer no seio do individualismo a estrutura hierárquica que, como sugeriu Dumont (2001b), em situações normais é obscurecida pela contradição de que, na sociedade moderna, a parte que é o indivíduo é o elemento englobante. Nos casos vistos aqui, por sua vez, a paisagem do mundo natural reservada aos humanos acaba, ironicamente, lembrando mais a Grande Cadeia do Ser medieval, na qual "a descontinuidade entre os tipos de seres diferentes é vista como uma continuidade do Ser como um todo" (Dumont 2001b:282). O todo englobante ainda é o indivíduo, mas o indivíduo equacionado ao "humano" (ou à "vida humana"); já em suas atualizações concretas, estes humanos são hierarquizados segundo o seu grau de completude e eficácia funcional, até o ponto em que alguns deles (o blastócito ou o pré-embrião) situam-se em posição tão inferior na escala hierárquica que, ao modo de um renunciante hindu, acabam "expelidos" do reino dos humanos-sujeitos para o dos nãohumanos-objetos.

A fórmula que aprendemos nas aulas de biologia, segundo a qual "a ontogênese [desenvolvimento embrionário] recapitula a filogênese [evolução da espécie]", embora hoje tecnicamente contestada em certos pontos pelos próprios biólogos, empresta sentido à condição especial do embrião: em seu estágio inicial de desenvolvimento, ele se situaria em posição análoga, no nível da evolução da própria espécie humana, àqueles primeiros exemplares do Homo sapiens muito mais próximos da animalidade (portanto, da potencial condição de objeto) que os humanos de hoje.

Se isto é verdade, a questão que nós, modernos, estamos atacando, com um pouco mais de pompa e alarde, é uma bem mais geral: trata-se do próprio problema da humanização, da construção da fronteira que circunscreve aquilo que concebemos cosmologicamente (o que, no caso do Ocidente moderno, também significa biologicamente) como "nós". Uma diferença em relação 
aos não-modernos seria que, numa cosmologia ancorada na ciência como forma de acesso a uma natureza única e na igualdade como valor máximo (Dumont 2001b) — ou, ainda, que equaciona o "humano" ao indivíduo — este "nós" supostamente abrange a humanidade como um todo. Neste sentido, a especificidade e a radicalidade do uso do embrião humano na pesquisa científica parecem sustentar a proposta dumontiana (Dumont 2001b) de que, no caso dos modernos, seria o indivíduo a própria "dobradiça" entre os mundos social e natural; ou seja, a natureza é constituída de "fatos" não apenas porque seu pólo ontológico, os "valores", foram idealmente relegados pela ciência ao domínio separado da sociedade (como sugere Latour 1997, 1999), mas porque esta é uma sociedade de indivíduos.

O mundo natural dos modernos só pode ser objetivo, pois os valores foram deslocados para o foro individual, fazendo da natureza "um mundo sem o homem, um mundo do qual o homem se retirou deliberadamente e sobre o qual ele pode, assim, impor sua vontade" (Dumont 2001b:291). Ingold (1991) também destacou tal "desengajamento" como condição para o estatuto de humanidade entre os modernos: "um mundo só pode ser 'natureza' para um ser que não pertence a ele [...] [A] possibilidade de desengajamento [...] é o marco para a condição da humanidade" (:13). Aí estaria a fonte do "prometeísmo" típico do homem moderno, que sustenta interferências sucessivas no mundo natural, como as diferentes formas de manipulação genética. Porém, no caso do embrião, trata-se justamente de interferir numa parcela deste mundo natural que era até então considerada humana, e que, para poder ser utilizada como meio, cumpriu que fosse "desumanizada", relegada a uma condição mais próxima à da animalidade (lembremos a referência do Relatório Warnock ao embrião como um "sujeito animal", trazida acima). Dessa forma, colocar em questão o estatuto de "indivíduo" do embrião para legitimar seu uso como meio na pesquisa científica implica diretamente uma reformulação de seu status ontológico enquanto parte do mundo natural.

Mas tal processo, como se viu, não é absoluto nem definitivo. O caso brasileiro, prenhe de ambigüidades, aponta nitidamente nesta direção: como ficou claro inclusive no discurso dos experts, embora atuando como objeto, como meio terapêutico, o blastócito permanece compartilhando com os sujeitos-fins a categoria frouxa da "vida": "uma vida que vale a pena sacrificar em prol de outras vidas". Ele, e mesmo o pré-embrião, ao deixarem a província ontológica dos sujeitos para adentrarem na dos objetos, não tiveram as portas trancadas atrás de si; assim, não seria surpresa se, eventualmente, eles retornassem. 
Recebido em 16 de maio de 2007

Aprovado em 10 de setembro de 2007

Letícia da Nóbrega Cesarino é doutoranda em antropologia social e cultural pela University of California, Berkeley. E-mail: <leticia.cesarino@gmail.com>.

\section{Notas}

* Agradeço os valiosos comentários feitos a uma versão preliminar deste texto pelos membros do Laboratório de Antropologia do Corpo e da Saúde (LACS) da UFMG, em especial seu coordenador, o prof. Eduardo Viana Vargas. Também a Naara Luna, pelas discussões virtuais em torno do tema.

${ }^{1}$ Outras referências ao HFEB foram feitas por Franklin (1999), Strathern (1992), Salem (1997), Kirejczyk (1999), Morgan e Lee (1991), além do próprio Mulkay (1997).

${ }^{2}$ Segundo Mulkay (1994a), as resistências a esta proposta partiram dos dois assistentes sociais, de um representante jurídico, do teólogo, da autoridade de saúde, do clínico geral e de um cientista. Estes membros da Comissão defendiam ou a total proibição da pesquisa com embriões, ou que fossem utilizados apenas os excedentes congelados nas clínicas de fertilização in vitro (FIV).

${ }^{3}$ Mulkay (1994a:638) comenta ainda que, não obstante seu papel definitivo de significante científico durante a tramitação do HFEB — o termo pré-embrião havia sido originalmente cunhado por um leigo - nunca se tornou consenso na comunidade científica, e nem mesmo consta no texto final da Lei de 1990.

${ }^{4}$ Neste ponto, a semelhança com o discurso pró-transgênicos no Brasil e alhures é notável (cf. Cesarino 2006).

${ }^{5}$ Atribui-se o feito a dois desenvolvimentos simultâneos, mas separados, de cientistas norte-americanos, publicados no mesmo mês de novembro: um na Science (Thomson et alii 1998) e outro na Proceedings of the National Academy of Sciences USA (Shamblott et alii 1998) (Dolgin 2003:100-1).

${ }^{6}$ Como explicado pelos cientistas participantes das audiências, as células-tronco adultas podem ser obtidas através de anexos embrionários, como o sangue do cordão umbilical, além de órgãos de indivíduos adultos, como a medula óssea. A grande 
maioria dos resultados já divulgados de terapia celular bem-sucedida advém do tratamento com este tipo de técnica. Já as células-tronco embrionárias são retiradas do embrião entre quatro e cinco dias após a fertilização, fase em que aparece como um conjunto de aproximadamente uma centena de células indiferenciadas, denominado blastócito. No nível atual de desenvolvimento técnico, ao serem retiradas as CTEs, o blastócito é destruído.

${ }^{7}$ Ricardo Ribeiro dos Santos (coordenador do Instituto do Milênio de Bioengenharia Tecidual e pesquisador da Fiocruz), em entrevista no Jornal da Ciência, em 24/02/2006.

${ }^{8}$ A FPE reúne parlamentares de denominações evangélicas diversas; na legislatura que se iniciou em 2003, contava com 62 deputados e 4 senadores. Compunham a terceira maior bancada da Câmara dos Deputados. Já a Bancada Católica no Congresso formava, na mesma legislatura, um grupo informal com 50 membros. Além da organização parlamentar, os católicos contavam com o tradicional lobby direto da Confederação Nacional dos Bispos do Brasil (CNBB) junto ao Legislativo e ao Executivo (Cesarino 2006:123-125).

${ }^{9} \mathrm{O}$ fundamento textual da recusa tanto do aborto como da pesquisa com embriões, comumente evocado pelos parlamentares cristãos a partir das Escrituras, era o Salmo 139, no qual o salmista diz a Deus: "Teus olhos fitaram meu ser ainda não formado, pois em Teu livro estão registradas todas as criaturas que, a seu tempo, serão criadas" (Cesarino 2006:125). Apesar do dogmatismo com que costuma ser defendida, tal concepção sobre o início da vida é surpreendentemente recente: data de 1869, quando o Papa Pio IX reconheceu que o feto é dotado de alma desde a concepção (Dolgin 2003:116-7).

${ }^{10}$ Além dos drs. Mayana Zatz e Dráuzio Varella, participaram Marco Antônio Zago, diretor científico do Hemocentro da USP de Ribeirão Preto e coordenador do Centro de Terapia Celular, e Patrícia Pranke, da UFRGS, além do senador Tião Viana (PT/AC), em sua qualidade de doutor em Medicina Tropical. André Soares, professor de bioética da PUC/RJ, foi o único que se manteve contrário à pesquisa com os embriões (Cesarino 2006:134).

${ }^{11}$ A clonagem terapêutica chegou a ser prevista no Substitutivo do primeiro relator do projeto na Casa, senador Osmar Dias (PDT/PR), mas não constou no Relatório seguinte, de autoria de Ney Suassuna (PMDB/PB). Foi cedida como moeda de troca nas negociações com as bancadas cristãs (Cesarino 2006:64). Em fins de 2005, a também chamada "transferência de núcleo somático" (técnica que consiste na transferência do núcleo de uma célula somática para um óvulo anucleado, dando origem a um novo conjunto celular do qual são retiradas as células-tronco) viria a ser alvo de um dos maiores escândalos recentes na comunidade científica: descobriu-se que os experimentos pioneiros com a técnica desenvolvidos pelo cientista sul-coreano Woo Suk Hwang e publicados na revista Science eram uma fraude (Jornal da Ciência no 2923, 26/12/05). 
${ }^{12}$ Em fins de março de 2005, logo após a aprovação definitiva da Lei de Biossegurança, um censo da Sociedade Brasileira de Reprodução Assistida revelou a existência de 9.914 embriões congelados nas 15 maiores clínicas brasileiras, estando apenas 3.219 deles congelados há mais de três anos. Assim, a cifra real de embriões potencialmente disponíveis para a pesquisa segundo os critérios da nova Lei representava um décimo da previsão avançada pelos cientistas - o que leva a crer que este era mais um argumento de pressão do que uma estimativa verossímil (Folha de S. Paulo, 31/03/05).

${ }^{13} \mathrm{O}$ que não quer dizer que uma defesa da ética do procedimento não tenha sido tentada. Assim como os cientistas britânicos colocaram a seleção genética como não alterando a "natureza" dos embriões, os especialistas brasileiros argumentaram que a terapia com as células-tronco embrionárias não seria mais que um desenvolvimento de técnicas anteriores de cultura de tecidos, eticamente legítimas (Cesarino 2006:136).

${ }^{14} \mathrm{Na}$ falta de uma lei federal regulamentando o tema, a norma em vigor passava pela Resolução $\mathrm{n}^{0}$ 1.358, de 1992, do Conselho Federal de Medicina, que proíbe o descarte dos embriões - porém sem "força de lei", o que tornava a prática, segundo os experts, freqüente nas clínicas de fertilização. O projeto de lei de tramitação mais avançada sobre o tema, de número 1.184/2003, já foi relatado no Senado e encontrase na Comissão de Constituição e Justiça da Câmara dos Deputados. Entre outros, ele determina a transferência a fresco de todos os embriões produzidos in vitro, no máximo dois a cada ciclo (o que evitaria a própria necessidade de congelá-los) (Cesarino 2006; Diniz 2003).

${ }^{15}$ Por exemplo, Beck 2003, Latour 1999 e Dupont 2004, além da edição do L'Année Sociologique de 1996.

${ }^{16}$ Franklin (1993) também destacou o caráter "não-relacional" do debate britânico, ancorado na linguagem objetiva da biologia, que tendia a tornar invisíveis referências ao parentesco e aos laços sociais do embrião in vitro.

17 Apesar de algumas das características atribuídas ao conjunto celular que forma o "pré-embrião" já apontarem neste sentido, notadamente a de "totipotencial" (Mulkay 1994a:630), ou seja, a capacidade de se diferenciar em qualquer tipo de tecido humano. Quando as primeiras células-tronco embrionárias humanas foram cultivadas em 1998, o debate normativo em torno dos experimentos a elas relacionados passou a se dar no âmbito da Human Fertilisation and Embriology Authority, com particular ênfase na clonagem terapêutica (Plomer 2003).

${ }^{18} \mathrm{O}$ mais conhecido defensor de uma ética assumidamente utilitarista é provavelmente o filósofo australiano Peter Singer, autor do polêmico Practical ethics (1999 [1979]), entre outros. 


\section{Referências bibliográficas}

BECK, Ulrich. 2003 [1986]. La société du risque. Paris: Flammarion.

CANNELL, Fenella. 1990. "Concepts of parenthood: the Warnock Report, the Gillick Debate, and modern myths". American Ethnologist, 17(4):667-86.

CESARINO, Letícia. 2006. Acendendo as luzes da ciência para iluminar o caminho do progresso: uma análise simétrica da Lei de Biossegurança Brasileira. Dissertação de mestrado, Universidade de Brasília.

DINIZ, Débora. 2003. "Tecnologias reprodutivas conceptivas: o estado da arte do debate no Legislativo Brasileiro". Jornal Brasileiro de Reprodução Assistida, 7(3):10-19.

DOLGIN, Janet. 2003. "Embryonic discourse: abortion, stem cells, and cloning". Florida State University Law Review, 31(1):100-162.

DUMONT, Louis. 2001a [1966]. Homo hierarchicus. Le système des castes et ses implications. Paris: Gallimard. 2001b [1983]. "La valeur chez les modernes et chez les autres". In: Essais sur l'individualisme. Une perspective anthropologique sur l'idéologie moderne. Paris: Seuil. pp. 254-299.

DUPONT, Yves (org.). 2004. Dictionnaire des risques. Paris: Armand Colin.

EDWARDS, Jeanette et alii. 1993. Technologies of procreation: kinship in the age of assisted conception. London \& New York: Routledge.

FRANKLIN, Sarah. 1993. "Making representations: the parliamentary debate on the Human Fertilisation and Embryology Act". In: J. Edwards et alii (orgs.), Technologies of procreation: kinship in the age of assisted conception. London \& New York: Routledge. pp. 127-169.
INGOLD, Tim. 1991 [1990]. "Human worlds are culturally constructed against the motion". In: R. Ellen (org.), Group of debates in anthropological theory. Manchester: University Press. pp. 12-17.

1994. "Introduction". In: What is an animal? London \& New York: Routledge. pp. 1-16.

KANT, Immanuel. 1986 [1785]. Fundamentação da metafísica dos costumes. Lisboa: Edições 70.

KIREJCZYK, Marta. 1999. "Parliamentary cultures and human embryos: the dutch and british debates compared". Social Studies of Science, 29(6):889-912.

L'Année Sociologique. Études sur le risque et la rationalité, 46(2), 1996.

LATOUR, Bruno. 1997 [1991]. Nous n'avons jamais été modernes. Essai d'anthropologie symétrique. Paris: La Découverte. 1999. Politiques de la nature. Comment faire entrer les sciences en démocratie. Paris: La Découverte. .2000a [1988]. Ciência em ação. São Paulo: Unesp. .2000b [1998]. "Faktura: de la notion de réseau à celle d'attachement". In: A. Micoud \& M. Peroni (orgs.), Ce qui nous relie. La Tour d'Aigues: Editions de l'Aube. pp.189-208.

LUNA, Naara. 2007. Provetas e clones: uma antropologia das novas tecnologias reprodutivas. Rio de Janeiro: Editora Fiocruz

MCLAREN, Anne. 1986. "Embryo research". Nature, 320:570.

MORGAN, Derek \& LEE, Robert. 1991. The British Human Fertilization and Embriology Act 1990: abortion and embryo research, the new law. Londres: Blackstone. 
MULKAY, Michael. 1993. "Rhetorics of hope and fear in the great embryo debate". Social Studies of Science, 23(4):721-42.

.1994a. "The triumph of the preembryo: interpretations of the human embryo in parliamentary debate over embryo research". Social Studies of Science, 24(4):611-39.

.1994b. "Changing minds about embryo research". Public Understanding of Science, 3:195-213. . 1994c. "Embryos in the news".

Public Understanding of Science, 3:33-51. . 1994d. "Women in the parliamentary debate over embryo research". Science, Technology \& Human Values, 19:5-22. . 1995a. "Parliamentary ambivalence in relation to embryo research". Social Studies of Science, 25(1):149-163.

.1995b. "Galileo and the embryos: religion and science in parliamentary debate over research on human embryos". Social Studies of Science, 25(3):499-532. 1995c. "Political parties, parliamentary lobbies and embryo research". Public Understanding of Science, 4(1):31-55. 1997. The embryo research debate: science and the politics of reproduction. Cambridge: Cambridge University Press.
PLOMER, Aurora. 2003. "Direito, ética e política em relação à pesquisa com células-tronco no Reino Unido e nos Estados Unidos". In: J. Martínez (org.), Células-tronco humanas: aspectos científicos, éticos e jurídicos. São Paulo: Loyola. pp. 119-143.

RABINOW, Paul. 1999 [1992]. Antropologia da razão. Rio de Janeiro: Relume-Dumará.

SAHLINS, Marshall. 2003 [1996]. "A tristeza da doçura. A antropologia nativa da cosmologia ocidental". Teoria \& Sociedade, 11(2):112-173.

SALEM, Tania. 1997. "As novas tecnologias reprodutivas: o estatuto do embrião e a noção de pessoa". Mana. Estudos de Antropologia Social, 3(1):75-94.

SHAMBLOTT, Michael. 1998. "Derivation of pluripotent stem cells from cultured human primordial germ cells". Proceedings of the National Academy of Sciences USA, 95:13.726-31.

SINGER, Peter. 1999 [1979]. Practical ethics. Cambridge: University Press.

STRATHERN, Marilyn. 1992. Reproducing the future: essays on anthropology, kinship and the new reproductive technologies. Manchester: Manchester University Press.

THOMSON, James et alii. 1998. "Embryonic cell lines derived from human blastocysts". Science, 282:1145-47. 


\section{Resumo}

Com o advento das técnicas de fertilização in vitro no final da década de 70, abriu-se um debate mundial sobre o estatuto do embrião produzido em laboratório, assim como sua manipulação experimental na pesquisa científica. O objetivo do artigo é analisar comparativamente dois destes debates no âmbito dos parlamentos britânico e brasileiro. O primeiro resultou na Human Fertilisation and Embriology Act de 1990, e o segundo, nas disposições da Lei de Biossegurança de 2005 relativas às células-tronco embrionárias. A análise, partindo da literatura antropológica sobre o tema, pretendeu demonstrar não só a abertura contemporânea das fronteiras do "humano" a uma negociação explicitamente política, como também os principais vetores que vêm conformando tais negociações no caso da pesquisa científica com embriões humanos.

Palavras-chave: Embriões, Células-tronco, Brasil, Reino Unido, Biossegurança

\section{Abstract}

Following the arrival of in vitro fertilization techniques at the end of the seventies, a worldwide debate soon flourished on the status of the embryo produced within the laboratory and on its use in experimental scientific research. The purpose of this paper is to analyze and compare two of these debates as they unfolded in the British and Brazilian Parliaments. The former resulted in the 1990 Human Fertilisation and Embryology Act, while the latter led to the provisions of the 2005 Biosafety Law concerning embryonic stem cell research. Exploring the anthropological literature on the topic, the analysis aims to show not only the contemporary opening up of the borders of the 'human' to explicitly political forms of negotiation, but also the main vectors directing such negotiations in the case of scientific research using human embryos.

Key words: Embryos, Stem cells, Brazil, United Kingdom, Biosafety 